\title{
A Critical Comparative Evaluation of English Course Books in EFL Context
}

\author{
Saeed Roshan \\ PhD student in languages, AUT Tower, corner of Wakefield and Rutland Streets, the \\ Auckland University of Technology, Auckland, New Zealand \\ E-mail: saeedrosh10@gmail.com
}

Received: Jan. 27, 2014 Accepted: February 12, 2014 Published: February 12, 2014

doi:10.5296/jse.v4i1.4990

URL: http://dx.doi.org/10.5296/jse.v4i1.4990

\begin{abstract}
Choosing an English course book which suits students in EFL/ESL settings is always a contentious issue for practitioners. This study is an investigation into the comparative critical evaluation of New Interchange Intro and New Headway Pre-intermediate series - two well-known series employed in EFL/EFL contexts - and some teaching challenges the teachers encounter during teaching these books in the context of Iran. The evaluation is done in terms of two assumptions; firstly, cultural and ideological assumptions, and secondly, assumptions about language, language learning and best practice. Findings reveal that both New Interchange and New Headway texts reflect ideological and cultural assumptions through their focus on the US and UK way of life respectively. The pictures and the material are found biased towards the culture of these countries in their depiction of local cities and lifestyles and in the inclusion of subjects. Regarding assumptions about language, language learning and best practice, the books focus on both form and meaning, and the grammar included is inductive and implicit. In the context of Iran, however, New Headway seems to be better for school students while New Interchange would be suitable for students and persons who aim to migrate or travel overseas. The study gives some suggestions for improving the usability of these books in the context of Iran.
\end{abstract}

Keywords: culture, ideology, power, English course books, language learning, EFL 


\section{Introduction}

Today, it would seem that nearly everywhere in the world at least some of the people make use of the English language. Gray (2002) points out that globalization and English are connected in three ways. The first connection involves transactional corporations which have headquarters in areas such as Europe, North America and Japan. These centers are in electronic contact with other centers around the world and the English language is employed as a means of communication. The second connection involves an increase in the number of world organizations and globalized networks that utilize English. The third connection deals with the internet and its predominant use of English. Phillipson (1992) introduced the concept of 'linguistic imperialism' when discussing how the use of English language has grown at the expense of local languages. He points out that cultural and economic power in the world has allowed English to dominate other languages.

Throughout the 1990s writers such as Phillipson (1992) and Pennycook (1998) studied the global spread of English; the findings of these writers reveal that the spread of English throughout the world is linked to politics, and that English language teaching (ELT) practices are not culturally appropriate or value free. ELT course books are generally produced in English speaking countries and are designed to be used in English language classrooms around the world. Although these texts are designed to teach English, they carry cultural messages and have pedagogic and commercial purposes (Gray, 2002). English has become the universal language for communication, implementing regulations and convention, and settling disputes (Huang, 1999).

Furthermore, nowadays most course books resemble each other as most ELT publishers provide the course book writers with approximately the same set of guidelines for writing the content of the course books. These guidelines include two areas: inclusivity and inappropriacy. Inclusivity deals with a non-sexist representation of women in course books. The rationale for this guideline is that a negative representation may result in women learning less effectively and cause gender bias. Inappropriacy deals with the avoidance of subjects that could offend buyers and readers and thus affect purchasing of the texts. These course books then can be regarded as 'feminized' for ethical reasons, and sanitized' for commercial aims. The stronger of the two guidelines is ‘inappropriacy’ and its effect on commercial purposes (Gray, 2002).

\section{Background to the Study}

Prior to discussing the study, it is necessary to provide some information about the context in which English language textbooks are employed. Iran as an Islamic country has some special rules regarding English language schools. All language schools are under the observation of the Ministry of Education and anyone who wants to establish a language school must first get a Ministry license. In each city, there is a Ministry of Education representative who regularly checks language schools to make sure they are following the rules. For instance, boys and girls cannot go to the same language school; therefore, most language schools have two separate branches, one for boys and the other for girls. The tuition fees are also established by the Ministry of Education. Students usually go to English classes three times per week for ninety minutes each day in most language schools. Students' levels are identified through placement 
tests. Language school students are mostly made up of two groups: school and university students make up one group and those who want to migrate or travel overseas constitute the other group. High school students are the majority in number, as they want to improve their English to get good marks in school and prepare themselves for university entrance examinations. Most of these language schools use English language textbooks that are published by famous publishers worldwide. These books are mostly compiled in the West, but are used extensively in every part of the world.

\section{Study}

The New Interchange and New Headway series are two popular ELT texts used in a number of countries throughout the world. A considerable number of Iranian institutions, for example, employ these books to teach English to their learners. English in Iran is treated as a foreign language.

This study deals with a comparative critical evaluation of aspects of the New Headway Intro and the New Interchange Pre-intermediate series. The books are used in teaching English as a foreign/second language in Iran. Although all the material contained in the two books was evaluated, the most salient units have been selected for this study. The reason for choosing these salient units of the two books is that they are challenging for both teachers and students in terms of the cultural and ideological aspects of teaching and learning. On occasion, they lead to cultural concern in parents as well. It is pertinent to mention here that the author has extensive experience of teaching English in Iranian context. He has remained both a teacher and a manager of a language school in Iran for some years; as a teacher the author has used these texts with students and as a manager he has experienced some of the challenges these texts pose to teachers and learners’ parents.

\section{Analysis}

\subsection{Cultural and ideological assumptions}

In the following discussion the role of power in the selection of content is discussed first, followed by an examination of the ideological issues underlining the content of ELT course books.

The issues of power and politics occur at the macro-level of language policy and planning, but their impact on the micro-level is inevitable. This creates challenges for managers, teachers and students. In other words, although power and domination may appear invisible in education, they influence the structure of classroom life. According to Auerbach (1995) all decisions made by practitioners inside the classrooms are influenced by the social order outside the classroom. All pedagogical choices and practices are in fact ideological in nature and strongly influence learners' socioeconomic roles and choices.

Comparative analysis of the units reveals some cultural and ideological issues which are challenging for Iranian students, parents and teachers. Both New Interchange and New Headway course books include sections on 'dating'. For instance, New Interchange provides students with some ideas for a first date. Likewise, the question "Are these dating activities 
popular in your country?" assumes that 'dating' is practised in other cultures in a similar way to the United States (US). However, in Iran for example, the concept of 'dating' is not appropriate, as it is in many other Islamic countries. Thus, teachers encounter problems when they want to teach this topic. Thus, in general, teachers will provide students with general information about dating but will not discuss it in detail. This then is an example of the cultural norms of the US or the United Kingdom (UK) which are in contrast with other cultures particularly Islamic cultures. Furthermore, in the book there is a topic about a Fall Fashion Show which advertises Western clothes. Iranian women, however, do not dress in this way when they are going out. There are other topics, however, such as "City Museum Travel Movies" or "Library Lecture", which are more appropriate to the Iranian context as they are in keeping with the interests of Iranian students.

In another part of the New Interchange text mostly focuses on "Popular tourist attractions in the United States". There are pictures of The Golden Gate Bridge, The Museum of Science and Industry, The White House, and The Statue of Liberty. The reading section focuses on the Rockefeller Centre, Bryant Park, and St. Patrick's Cathedral. There are some pictures of stamps from the US as well. In these the units, the pictures are predominantly of Caucasian, Western women. Overall, the text and pictures are promoting the culture and attractions of the US. There is power and ideology behind the text and pictures that learners' are being exposed to.

New Headway also has a topic on 'dating' in the text - this time in the UK context. Once more the focus of the topic is not appropriate in the context of Iran. In the unit people discuss their love life - something that would cause embarrassment to an Iranian. Prior to marriage there is usually no romantic relationship between young men and women. Teachers in Iran therefore face problems when discussing such issues in class. In addition, most parents of students are not happy with such topics; they believe such topics are an attempt to assimilate their children into the culture of the West. However, young students are curious about these issues and will usually ask their teachers for more information. The section "Who do you think Matt will pick from these three lovely girls?” promotes the power of men to choose girls in a blind date. In addition, the lesson provides students with pictures and information about astrological star signs which again poses a difficulty for teachers who need to explain this interest of the West. Furthermore, there is the picture of the Sony Ericsson mobile and it can be interpreted that English language students around the world are being asked to buy Sony Ericsson products. Thus, language teaching methods could be employed based on culture and ideology and have both political and economic consequences. Generally, the methods used in language teaching reflect the social relations, the ways of thinking and learning strategies of the people who contact them (Pennycook, 1989)

There are some issues in the two books, however, which reflect intercultural competency. This section looks at the extent the two texts are participatory. Auerbach (1995) differentiates between the learner-centered and the participatory approach; the former emphasizes self-realization and the latter emphasizes social transformation, that is, "drawing curriculum content from the social context of learners' lives as well as involving them in curriculum development processes” (1993:543). Both units of the New Interchange text include the 
participatory approach. For instance, in New Interchange, the participatory approach could be reflected in some questions like "list three things you want to do. Then compare with a partner. Is there one activity you both want to do?" or "What shopping plans do you have this week? Tell your partner." In New Headway, the participatory approach can be included in the questions such as, "What's your star sign? Find out all the star signs in the class. Which is the most common?" or "Do you know anyone who has lived or is living in another country? What did/do they think of it? All questions in this part are also open ended.

\subsection{Assumption about language, language learning and best practice}

A considerable amount of research in second language acquisition has been directed at understanding and contributing to more effective language learning instruction. However, neither research nor theory clearly identifies the best means of facilitating language learning. In particular, there is considerable controversy concerning whether or not instruction should focus on form or forms approaches. There is also no agreement about the efficacy of teaching implicit and explicit knowledge or about the best type and manner of employing corrective feedback (Ellis, 2005). Scholars such as Ellis (2005), Brown (2007), Nation and Macalister (2011), Kumaravadivelu (2003), Richards \& Renandya (2002) and have illustrated the principles of best practice when teaching a second language. Using their principles the following analysis is offered for the selected units. Communication to language (inductive) and language to communication (deductive) are regarded as two broad approaches to language teaching.

In case of New Interchange the tasks are mostly communicative (e.g. "What shopping plans do you have this week? Or "What are your favorite dating activities?" Or "write down three things you want to do this weekend, with the day and time"), some controlled practice (e.g. complete these responses with'd love to, 'd like to, have to, or need to) and the grammar approach is inductive. However, in New Headway units, although some tasks are communicative (e.g. how many good friends do you have? Do you have a best friends? Why is he/she your best friends?), most tasks are control practices (e.g. mach the verbs with the words or phrases). The approach in grammar is inductive since learners are required to discover the rules of grammar.

In addition, both the New Interchange and New Headway texts include meaning focused input in the form of listening and reading and meaning focused output in the form of production such as pair work and group work. The New Interchange text focuses more on listening and speaking than reading and writing. That is, it appears its main goal is to improve communication skills. This is why in Iran most language schools include supplementary activities to this text such as reading short stories and writing letters and essays. Because of its communicative nature, however, most English teachers recommend that those who want to travel overseas study from this text. The New Headway text focuses more on reading and writing. The lessons include long readings, a great deal of new vocabulary and writing activities, in clear distinction from New Interchange. Thus, school students who need to develop their reading and writing skills to get good marks at school and to be successful in university entrance examinations are recommended to study from the New Headway text. 
Activities in both books also seek to provide learners with concurrent skill development opportunities - multiple skill requirement being reflective of real-life situations. For instance, in all four units there are activities that ask students to both listen and write.

\section{Discussion and Conclusion}

The current study deals with a comparative critical evaluation of four units in New Interchange Intro and New Headway Pre-intermediate series. The analysis reveals that both texts reflect ideological and cultural assumptions through their focus on the US and UK respectively. The pictures and the material are biased towards the culture of these countries in their depiction of local cities and lifestyles, and in the inclusion of subjects such as dating - an activity which is certainly not a norm in all countries - particularly in Islamic cultures. While these texts mostly focus on the cultural norms of the US and the UK, the majority of learners will be using English to interact with other multilingual speakers. In Iran, for example, not many of the learners that use these texts will actually go to the US or the UK in their lifetime.

Furthermore, the course outlines of the two texts include only assessable skills; anything which is invisible and cannot be assessed, for example, how to maintain relationships with people and how to manage culture shock, are not included. Thus, it is recommended that some supplementary materials such as how to cope with stress and anxiety in a new culture be added to course materials. It would be very useful for students aiming to travel and migrate other countries.

Although these two books favour the participatory approach, their focuses are superficial and do not include all of the issues which lead to intercultural awareness. For instance, in New Interchange the questions "Are these dating activities popular in your country?" assume 'dating' is an international norm. However, it could be appropriate to ask questions such as, "Does dating exist in your country? If yes, then answer these questions (e.g. what are your favorite dating activities) and if no, instead of dating how do young men and women become familiar with each other in your country?” In the context of Iran a family’s religious attitudes determine to what extent adult children are allowed to get to know a potential partner before marriage. If the family is not too traditional, adult children are allowed to get to know a potential partner for a period of time before deciding on marriage. In Iran this is called "Namzadi". By extending the questions to include cultural difference it is possible therefore to include Iranian students. Their background knowledge of Namzadi for instance would stimulate a great deal of discussion on the merits of dating/Namzadi. The texts, then, should include activities that push learners to offer a critical perspective on L1, C1 and L2, C2. In this way, superficial issues that relate to one culture can develop into meaningful issues for many cultures. As it is, even in an age of globalization, migration and cultural hybridity, these texts focus only on the cultures of the US and the UK. It is recommended therefore that in New Interchange supplementary materials are included such as teachers asking students to provide information about the attractions in their favourite countries and discuss these attractions in groups. In this way students will become familiar with the cultures of different countries. In terms of fashion shows, some Islamic countries, such as Malaysia, have recently established their own style of Islamic fashion shows; a teacher could show internet pictures of these shows 
and generate discussion among students: "Would you like to have this type of show in Iran as well? If yes - or no - what is your reason?” In such an activity students would be able to practice self-assessment regarding their culture.

Both the New Headway and New Interchange texts also reveal a close adherence to the issues of inclusivity. In the case of inclusivity, there is a special focus on women both in the pictures and in the interactions. They are also shown in a variety of roles, such as businesswomen, artists, and so on.

In terms of assumptions about language, language learning and best practice, these two texts focus on both form and meaning. Some scholars such as Brown (2007), Nation and Macalister (2011) and Kumaravadivelu (2003) point out that it is necessary to strike a balance between focus on form and meaning or between control and communicative activities. In the case of the units under discussion, the previous analysis shows that most of the activities especially in New Headway are controlled; thus it is recommended that some supplementary less controlled and communicative tasks be added to the units. The grammar approach in both texts is inductive and implicit; however, in the context of Iran, due to the importance English books put on grammar, school students need to know and learn grammar deductively and explicitly as well. Therefore, considering the needs of learners, it is suggested that Iranian teachers include the explicit and deductive approach in grammar alongside the inductive and implicit method.

It seems, therefore, that course book writers need to recognize the real need of learners and that those needs are inextricably linked with the learners' cultures. In other words, course books should not only reflect the culture they are written in, but also take into account the different norms of the cultures they are written for. Thus, course books should include intercultural competence and be designed to create a balance between form and meaning.

\section{References}

Auerbach, E.R. (1993). Putting the P back in participatory. TESOL Quarterly, 27(3), 543-544. http://dx.doi.org/10.2307/3587484

Auerbach, E.R. (1995). The politics of the ESL Classroom: Issues of the power in pedagogical choices. In J. Tollefson(Ed), Power and inequality in language education (pp.9-33). New York: Cambridge: University Press.

Block, D. (2008). Language education and globalization. In S. May \& N. Hornberger (Eds.), Encyclopedia of language and education. Springer.

Brown, D. (2007). Teaching by Principles: An Interactive Approach to Language Pedagogy. Pearson Longman.

Byram, M. (1997). Teaching and assessing intercultural communicative competence. Clevedon: Multilingual Matters.

Canagarajah, A. S. (2002). Globalization, methods and practice in periphery classrooms. In D. Block and D Cameron (Eds). Globalization and language teaching, (pp.134-150). London, Routledge. 


\section{Macrothink}

Journal of Studies in Education

ISSN 2162-6952

2014, Vol. 4, No. 1

Crystal, D. (1997). English as a global language. Cambridge: Cambridge University Press.

Ellis, R. (2005). Principles of instructed language learning. System, 33, 209-224. http://dx.doi.org/10.1016/j.system.2004.12.006

Gray, J. (2002). The global course book in English language teaching. In D. Block and D. Cameron (Eds). Globalization and language teaching, (pp. 151-167). London, Routledge.

Huang, Z. (1999). The impact of globalization on English in Chinese university. AILA Review, 13, 79-88.

Kumaravadivelu, B. (2003). Beyond Methods: Macrostrategies for Language Teaching. Yale University.

Macalister, J. \& Nation, I.S.P. (2011). Case Studies in Language Curriculum Design: Concepts and Approaches in Action Around the World (ESL \& Applied Linguistics Professional Series). Routledge.

Pennycook, A. (1982). English and the Discourses of Colonialism (The Politics of Language). Routledge.

Phillipson, R. (1992). Linguistic Imperialism. Oxford University Press.

Richards, J. C. (2000). New Interchange (Intro). Cambridge: CUP

Richards, J.C. \& Renandya, W. (2002). Methodology in language teaching. Cambridge: Cambridge University Press.

Soars, L\&J. (2003). New headway Pre-Intermediate. Oxford: OUP 